Discussion Paper No. 11-007

\title{
Variation of Learning Intensity in Late Adolescence and the Impact on Noncognitive Skills
}

Bettina Büttner, Hendrik Thiel, and Stephan L. Thomsen

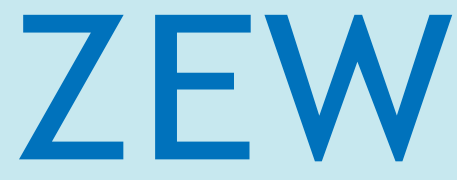

Zentrum für Europäische Wirtschaftsforschung $\mathrm{GmbH}$

Centre for European Economic Research 
Discussion Paper No. 11-007

\title{
Variation of Learning Intensity in Late Adolescence and the Impact on Noncognitive Skills
}

\author{
Bettina Büttner, Hendrik Thiel, \\ and Stephan L. Thomsen
}

Download this ZEW Discussion Paper from our ftp server:

ftp://ftp.zew.de/pub/zew-docs/dp/dp11007.pdf

Die Discussion Papers dienen einer möglichst schnellen Verbreitung von neueren Forschungsarbeiten des ZEW. Die Beiträge liegen in alleiniger Verantwortung der Autoren und stellen nicht notwendigerweise die Meinung des ZEW dar.

Discussion Papers are intended to make results of ZEW research promptly available to other economists in order to encourage discussion and suggestions for revisions. The authors are solely responsible for the contents which do not necessarily represent the opinion of the ZEW. 


\section{Non-technical Summary}

Recent research in economics reveals a substantial impact of personality traits or noncognitive skills on outcomes related to educational and labor market success. A virtue of these noncognitive skills compared to cognitive skills in terms of policy interventions is their malleability up to late adolescence. Therefore, the complete time at school may provide a crucial investment in the formation process of these skills, and returns on specific investments during that time are economically meaningful.

The aim of this paper is to investigate the potential role of a substantial change of learning intensity, i.e. the amount of curriculum per unit of time, throughout later secondary schooling with regard to personality development. To measure students' personality, we employ the Big Five Factors Openness to Experience, Conscientiousness, Extraversion, Agreeableness and Neuroticism. Furthermore, the Rotter Locus of Control, a measure of Self-Control and measures for Positive and Negative Reciprocity are used. In order to identify the causal relationship, we use an exogenously induced educational policy reform in Saxony-Anhalt, a German federal state, as a natural experiment. The reform was intended to reduce the time spent in higher secondary school by eliminating the final grade. Since the curriculum was roughly maintained, the reform gave rise to an increase in learning intensity.

Our results show no significant effect of the increased learning intensity on any of the personality scores considered. To eliminate potential confounding effects, we control for a simultaneous age effect and for a possible trade-off between schooling and extracurricular investments. The results therefore promote that the development of personality in late adolescence does rather not depend on schooling investments. 


\section{Das Wichtigste in Kürze}

Eine wachsende Zahl empirischer Studien der bildungsökonomischen Forschung zeigt die Bedeutung von Persönlichkeitseigenschaften und sog. nicht-kognitiven Fähigkeiten für die Erreichung bestimmter Bildungsgrade und anderer arbeitsmarktbezogener Zielgrößen. Dabei ist der Umstand, dass nicht-kognitive Fähigkeiten bis in das später Jugendalter formbar sind, von besonderer Relevanz in Bezug auf bildungspolitische Maßnahmen. Daher sind neben häuslichen Einflussfaktoren explizit schulische Faktoren und Investitionen im Hinblick auf die Entwicklung dieser Fähigkeiten zu untersuchen.

Die vorliegende Studie analysiert den Einfluss einer deutlichen Variation der Lernintensität, d.h. dem Verhältnis aus Lehrinhalt und Lernzeit, im Bereich der Sekundarstufe II auf die Entwicklung nicht-kognitiver Fähigkeiten. Zur Quantifizierung der Persönlichkeit werden neun unterschiedliche Maße verwendet. Diese umfassen die sogenannten Big Five Faktoren, d.h. Offenheit für Erfahrungen, Gewissenhaftigkeit, Extraversion, Freundlichkeit und Neurotizismus, sowie ein Maß für Kontrollüberzeugungen nach Rotter, ein Maß der Selbstkontrolle und eine Skala zur sog. positiven und negativen Reziprozität. Zur Identifikation des Zusammenhangs zwischen Lernintensitätsvariation und den erfassten Persönlichkeitsdimensionen nutzen wir ein natürliches Experiment, das sich durch die Umsetzung der der Schulzeitverkürzung am Gymnasium von neun auf acht Jahre (Turbo-Abi) im Land Sachsen-Anhalt im Zeitraum zwischen 2003 und 2007 ergeben hat. Der Zweck der Reform besteht darin, die Schulzeit im Hinblick auf die im Bologna-Prozess vereinbarten Ziele zu verkürzen. Da die Anforderungen im Abitur nahezu unverändert blieben, ging die Reform mit einer Erhöhung der Lernintensität einher. Grundlage der empirischen Analyse sind Daten einer Primärerhebung der Absolventen beider Jahrgänge.

Die Ergebnisse geben keinen Hinweis auf einen signifikanten Einfluss der Lernintensitätsvariation auf die untersuchten Persönlichkeitsmaße. Um die Möglichkeit potenzieller Verzerrungen der Ergebnisse durch Alterseinflüsse oder gegenläufig wirkende Rückgänge außerschulischer Faktoren auszuschließen, führen wir gesonderte Analyse für diese Größen durch. Insgesamt zeigen unsere Ergebnisse, dass die Formbarkeit der Persönlichkeit in der späten Jugend durch schulische Faktoren, die die Unterrichtsqualität beeinflussen, kaum mehr möglich ist. 


\title{
VARIATION OF LeARning Intensity in Late Adolescence AND the ImPACT ON NonCOGNITIVE SkILls*
}

\author{
Bettina Büttner ${ }^{\dagger}$ \\ University of Magdeburg \\ Hendrik Thiel ${ }^{\ddagger}$ \\ University of Magdeburg \\ Stephan L. Thomsen ${ }^{\S}$ \\ University of Magdeburg $\&$ ZEW, Mannheim
}

This version: January 27, 2011

\begin{abstract}
Despite the interdependence between cognitive and noncognitive skills, empirical studies have shown a longer period of acquisition in life-time for the latter besides relevance for educational and labor market success. Analyzing returns of investments during different periods of life is therefore economically meaningful. We evaluate the effects of a substantial increase in the amount of curriculum per unit of time (learning intensity) at the end of higher secondary schooling on nine types of these skills. The results show no influence on the acquisition of noncognitive skills, indicating that personality does rather not depend on schooling investments in late adolescence.
\end{abstract}

Keywords: noncognitive skills, human capital formation, learning intensity, natural experiment, Big Five, Locus of Control, Reciprocity, Self-Control

JEL Classification: I21, I28, J24, C21

${ }^{*}$ We would like to thank Michele Belot, Philipp Eisenhauer, Marjaana Gunkel, Guido Heineck, Verena Niepel, Friedhelm Pfeiffer, and Pia Pinger for their helpful comments. The paper has benefited from discussions at the workshop on "Academic Frontiers of Child Behavior" in Magdeburg and the applied economics seminar at University of Mannheim. Financial support from the Stifterverband für die Deutsche Wissenschaft (Claussen-Simon-Stiftung) is gratefully acknowledged. The usual disclaimer applies.

${ }^{\dagger}$ Bettina Büttner is Post-Doc Researcher at Otto-von-Guericke-University Magdeburg, Department of Economics and Management, PO Box 4120, D-39016 Magdeburg, e-mail: bettina.buettner@ovgu.de, phone: +493916718175.

${ }_{\ddagger}^{\ddagger}$ Hendrik Thiel is Research Associate at Otto-von-Guericke-University Magdeburg, Department of Economics and Management. Address: PO Box 4120, D-39016 Magdeburg, e-mail: hendrik.thiel@ovgu.de, phone: +49 3916718324.

${ }^{\S}$ Stephan L. Thomsen is Assistant Professor of Labor Economics at Otto-von-Guericke-University Magdeburg and Research Associate at the Centre for European Economic Research (ZEW) Mannheim.

Address: PO Box 4120, D-39016 Magdeburg, e-mail: stephan.thomsen@ovgu.de, phone: +49 3916718431 , fax: +49 3916711700 . 


\section{Introduction}

Recently, economic research has started to emphasize the crucial role noncognitive skills play in determining educational, economic and social outcomes (see, e.g., Bowles et al., 2001, Borghans et al., 2008b). As opposed to cognitive skills, noncognitive skills are malleable beyond preschool age (see, e.g., Cunha et al., 2010). Evidence from neuroscience states that the prefrontal cortex, which governs the behavioral pattern of personality, is malleable at least until age 20 (see Dahl, 2004). Specific traits, like conscientiousness, even show mean-level peaks until age 30 (see, e.g., Roberts et al., 2006, Blonigen et al., 2008). For this reason, besides various investments related to a child's home environment the time at school may provide a crucial investment in the formation of these skills. The relationship between schooling investments and noncognitive abilities for teenagers/young adults has been studied by Heckman et al. (2006) analyzing the effects of these abilities on various social and labor market outcomes. Their estimates indicate a substantial variation of noncognitive skills by schooling choices, but cannot explain the formation of noncognitive skills due to schooling. Measuring the effects of schooling choices and schooling investments on these abilities is furthermore limited due to a considerable paucity of empirical data on the individual level in many countries (see, e.g. Todd and Wolpin, 2007). Typical indicators usually refer to the class level and comprise, for example, student/teacher ratios, teacher qualification, and resources per student. These inputs into the noncognitive skill formation process have weak effects for early years of schooling, see e.g. Cunha et al. (2010).

The aim of this paper is to analyze the role of an alternative dimension of schooling investments with regard to personality development in late adolescence, and therefore to contribute to the scarce economic literature on educational investment during that period. To do so, we utilize primary data obtained from students participating in a large educational policy reform in Saxony-Anhalt, a German federal state. In course of the Bologna Process ${ }^{1}$, almost all German federal states implemented policies designed to reduce the time spent in higher secondary school by eliminating the final grade, i.e. the 13th year of schooling. In Saxony-Anhalt, this reform was announced in 2003 for students in grade 9 at that time. The abolishment of the last year of schooling was introduced without commensurably reducing the scholastic requirements for graduation, and the academic curriculum remained almost unchanged. Therefore, the learning intensity, that is, the academic curriculum content per unit of instructional time, for the new 12-year graduates increased considerably by about 20 percent. Since for students in grade 10 in 2003 the 13-year graduation was maintained, the reform can be assumed to provide a natural experiment with a double cohort of graduates in 2007. This is used to identify the effect of the substantially increased learning intensity on the development of noncognitive skills in late adolescence. Although a circular dependency of learning intensity and noncognitive skills is very likely in many situations, the reform exogenously introduced a uniform increase of learning intensity to all students receiving the treatment. Thus, it can be interpreted as a measure of curricular investments in school. The stock of noncognitive skills is measured by means of three personality

1 The Bologna Process is the process of creating a European Higher Education Area (EHEA) by 2010, one that includes the adoption of the academic degrees (Bachelor, Master, and Doctorate) together with the introduction of a credit transfer system that recognizes higher educational course work done at other locations. 
assessment constructs adopted from the psychological field and one measure originating from the field of experimental economics. As a complete personality inventory, we choose a short version of the BigFive inventory (comprising Openness to Experience, Conscientiousness, Extraversion, Agreeableness, Neuroticism) which dates back to the work of Goldberg (1971). The remaining measures are chosen with respect to their relevance in explaining human capital issues. We use a short version of the Locus of Control scale established by Rotter (1966), the Brief Self-Control Scale (Tangney et al., 2004 ), as well as Positive and Negative Reciprocity (Fehr and Gächter, 2000). ${ }^{2}$

The interpretation of the estimated impact on personality is twofold. First, the countries of the European Union have a converging educational structure. Evaluating the direct effects of an educational reform, like the one implemented in Saxony-Anhalt, beyond outcomes of pure grade achievements thus provides important insights of value for future educational decisions. The second implication of our investigation is to narrow the gap of indeterminacies regarding the role of schooling inputs in the noncognitive skill formation process in later adolescence. A number of authors have studied the process of skill formation in early periods of life. For example, Heckman et al. (2010) analyze the longterm effects of the High/Scope Perry Preschool Programme, Gupta and Simonsen (2010) estimate the effects of attending a preschool versus family day care on the development of noncognitive skills at the age of 7 , or Weiss (2010) investigates whether different school tracking systems affect the influence of cognitive and noncognitive skills at age 11 on later earnings. Cunha et al. (2010) formulate and estimate a multistage model, where cognitive and noncognitive skills are determined by home investments at different periods of childhood. They find evidence for malleability of noncognitive skills until age 14, while cognitive skills are exclusively malleable in early life (see also Borghans et al., 2008b); but, it should be noted that the results may be due to right-censoring of the data used since the age-span covered by the CNLSY ends at age 14. In spite of these important findings, less research exists on schooling factors throughout stages of later secondary education enhancing noncognitive skills. Understanding the determinants of cognitive skills and personality traits as well as their interactions in the skill formation process can lead to a better understanding of long-run outcomes and is important for drawing policy implications.

To the best of our knowledge, this is the first study which evaluates the effects of a substantial educational reform in late adolescence on student's personality. The loss of a whole instructional year without a compensating reduction in the graduation requirements reduces the time available for instruction, for homework, and for extracurricular and leisure activities. This results in strong negative effects of the reform on the academic achievement as shown by Büttner and Thomsen (2010). In contrast to those findings, we cannot discover any significant effects of an increased learning intensity on the various noncognitive skills. Despite the relevance for academic discussions, this result is also of political importance. Massive protests in the German federal states which currently implement the educational reform aim for reversing the reform. The involved students, parents, and teachers claim the return to longer higher secondary schooling in order to improve the students' personality.

$2 \quad$ See Borghans et al. (2008a) and Thiel and Thomsen (2009) for overview papers related to the role and measurement of individual's personality in economics. 
Our results show that this claim is not qualified: The educational reform does not affect student's personality.

The remainder of the paper is organized as follows. The following section provides background information on the educational reform to highlight its interpretation as a natural experiment, as well as a theoretical exposition of the process of skill formation and the parameters of interest. The primary data used in the empirical analysis are introduced in section 3 together with some selected descriptive statistics describing the analysis sample. Section 4 provides the empirical estimates of the reform effects and the effects of further background variables considered in the estimation on noncognitive skills. Moreover, robustness checks of the estimation are provided at the end of the section. The final section discusses the results of the analysis.

\section{The Educational Reform of Higher Secondary Schooling in Ger- many}

\subsection{Institutional Background}

In Germany, the responsibility for educational policy including the funding of public schools is entrusted to the Bundesländer (the German federal states). Despite this decentralized nature of responsibility, the differences in the educational systems between the single federal states are rather marginal. Usually, students are enrolled in primary school at the age of six and remain there for four years. Upon completion, they are guided, according to their scholastic achievements, into three available types of secondary schooling: the basic, the intermediate, and the university preparatory. The Hauptschule is the basic secondary school and provides educational instruction through the ninth grade, the minimal required length of schooling. The Realschule provides the intermediate level of instruction through the tenth grade. Afterwards, the graduates from both of these types of schools usually commence some sort of vocational training in the German apprenticeship system. Until recently, all federal states (except for Saxony and Thuringia) provided nine years of university preparatory schooling in their Gymnasium leading to the Abitur (university admittance qualification). In addition to these three types of schools, several states provide an additional type of comprehensive schooling, the Integrierte Gesamtschule (a comprehensive school). In this school, students can graduate after nine, ten, or thirteen years. As such, they are able to obtain the same (and identically valued) academic degrees as offered by the main three types of secondary schooling. The significant difference of this type of schooling is that the students are not guided into a specific academic path beforehand.

The on average higher age of university graduates compared to graduates from other developed countries gave rise to a debate about reforming higher secondary schooling duration. The observed higher age at university graduation resulted from a longer university curriculum coupled with a prolonged period of secondary schooling (OECD, 2005). Recently, the university curriculum has been reformed as a result of the Bologna Process, originating with the signing of the Bologna Declaration in 1999, 
that postulated the creation of a European Higher Education Area (EHEA) by 2010. Within the process the former German academic degrees (in particular the Diplom) have been replaced by the adoption of the international academic degrees (Bachelor and Master) together with the introduction of a credit transfer system that recognizes higher educational course work done at other locations. Nevertheless, the Bologna Process also increased the pressure upon Germany to reform the higher secondary schooling system.

The German state Saxony-Anhalt initiated an educational policy reform that shortened the length of higher secondary schooling by one year. Recently, almost all German states have followed and decided to eliminate the last year of secondary schooling. The change was announced in 2003 and was implemented some months later at the beginning of the 2003/2004 academic year. The first students to be affected by this change were in the ninth grade at that time. Hence, they were the first students to receive their Abitur after twelve years of schooling (henceforth referred to as G12). The academic requirements for the Abitur, however, remained almost unaltered. For students in the tenth grade at that time (referred to as G13 afterwards) graduation after 13 years of schooling has been maintained. Consequently, in spring 2007 a double cohort (G12 and G13) of students simultaneously passed their final year of schooling and graduated. For admission to the final examinations of Abitur the achievement during the last two years of schooling is relevant. In the reform, this rule remained unaffected. The academic curriculum of the twelfth and thirteenth grades had been pushed forward by one year. For the G12 students, the curriculum of the former eleventh grade, called the preliminary grade, was distributed throughout the lower grades. The whole curriculum was moved forward in German literature as well as in the foreign languages. Only minor reductions were implemented in mathematics and chemistry, whereas in some other subjects, e.g. biology and history, parts of the eleventh grade curriculum were transformed into elective courses.

The total instructional time for the G12 students had been reduced by one academic year, which corresponds to an increase of total learning intensity by about 20 percent. This loss of a whole instructional year without a compensating reduction in the graduation requirements reduces the time available for instruction, for homework and for extracurricular and leisure activities. It was eased, however, by the addition of some extra classroom hours. Three instructional hours per week were added in the ninth grade and three in the tenth grade. Schools were allowed to decide, to which subjects the additional instructional hours were allocated. With regard to scholastic achievement scores, Büttner and Thomsen (2010) find important reform effects on student performance. G12 students scored significantly worse in mathematics compared to G13 students independently of gender. Beyond these differences the shortage of time may affect student's personality. Illustrating two possible pathways, we could hypothesize that forcing students to prepare higher secondary school graduation earlier in the life-cycle may increase their self-discipline, on the one hand. On the other hand, it may also be likely that learning requirements become too strong and people loose self-confidence. In order to systematize the possible effects of the reform, it is useful to consider some theoretical arguments as the baseline of the later empirical analysis. 


\subsection{Theoretical Considerations}

Cunha and Heckman (2007) and Heckman (2007) suggest a model of the evolvement of cognitive and noncognitive skills throughout childhood and adolescence. Though the primary interest of that model is to operationalize the development of noncognitive skills mostly rewarded in the labor market (like Locus of Control), we suggest to adopt the analytical framework and its notions to sketch possible impacts of the educational reform that increases learning intensity considerably on all assessed dimensions. This skill formation technology recursively models skills of the current period as a function of current investments into the formation process and previously acquired skills.

The crucial features of this set-up are self-productivity and dynamic complementarity. The first feature, self-productivity, postulates that skills acquired at one stage are always also part of the skills available at later stages. The second, dynamic complementarity, considers the issue that a higher level of skills at an earlier stage increases the return on investments conducted in the ensuing stages. It results from complementarity between the inputs at a specific period and the recursive fashion of the production technology. Consequently, early investments are more effective than later ones but, vice versa, they should be maintained.

Applying these considerations to our setting and using a non-recursive notation, the following inputs determine the instantaneous stock of noncognitive skills $\boldsymbol{\theta}_{t}$, where $t$ is the period ensuing the point in time when the personality test was conducted after graduation:

$$
\boldsymbol{\theta}_{t}=f\left(\boldsymbol{\theta}^{*}, \boldsymbol{I}_{t-1, S}, \boldsymbol{I}_{t-1, H}\right),
$$

$\boldsymbol{\theta}^{*}$ denotes the stock of noncognitive skills acquired up to the point in time, when the reform was enacted. The period $t-1$ is the time afterwards. It is sensible to differentiate the investments during that period into schooling investments $\left(\boldsymbol{I}_{t-1, S}\right)$, that are directly influenced by curricular changes, and into investments into the extracurricular environment $\left(\boldsymbol{I}_{t-1, H}\right)$. This differentiation is reasonable as we could expect a trade-off between both types of investments due to time constraints. Clearly, increasing the learning intensity by shortening secondary schooling and, therefore, increasing the time required to attend school and to prepare homework comes at the cost of potential investments into the extracurricular environment. With regard to the development of the noncognitive skills, the effect is ex ante not defined. Ceteris paribus, an increase in instructional intensity is tantamount to an increase of schooling investment in the respective period $t-1$. In addition, there may be also a decline in extracurricular activities, which is likely to counteract the former effect. Depending on which effect dominates, the aggregate reform effect on the particular measure of noncognitive skills can be positive, negative or zero.

\subsection{Identification in a Natural Experiment}

In this paper, we want to analyze the effect of a substantial change in $\boldsymbol{I}_{t-1, S}$ and the associated change in $\boldsymbol{I}_{t-1, H}$ on $\boldsymbol{\theta}_{t}$. The policy reform in Saxony-Anhalt provides a natural experiment that allows to 
identify the parameter of interest. The main advantage is that the assignment to the treatment group, i.e. students graduating after 12 years (G12), and to the comparison group, i.e. students graduating after 13 years (G13), could be assumed to be random conditional on the policy reform. Under this assumption, assignment to any group is independent of all factors determining $\boldsymbol{\theta}^{\star}$, comprising - besides others - parental investments and background up to that time. Then, differences in the noncognitive skills at time $t$ between treatment and control group can be interpreted as the causal effect of the reform.

Nevertheless, although the implementation of the educational reform resembles the situation of an experimental situation to analyze the question of interest and to identify the corresponding parameters quite well, there are a number of threats to the validity of the natural experiment that should be regarded carefully. Particularly, if the selection into treatment group and comparison group is not exogenous and members of both groups differ in a systematic way, the outcomes will be affected. In the case under consideration, however, this is not very likely. As described above, the reform was announced and implemented immediately. Therefore, no reaction on tracking results since students have been attending the academic track for several years already. In line with that, the that-time secretary of education and cultural affairs of Saxony-Anhalt, Jan-Hendrik Olbertz, pointed out that "The introduction of the Abitur after 12 grades ran surprisingly smoothly". If there is any systematic selection beyond the policy reform between groups, this should be observable when comparing the pretreatment characteristics of the sample (see below). Reasons for this selection could be the anticipation of the reform, and persons decide to move to a different state within Germany in a very short time span. However, costs of movement would be extraordinarily high particularly for the parents of students as they will have to find a new job and may have to sell their housing property. Therefore, this type of anticipation effect seems to be not very likely. Alternatively, children could be required to commute to a school in a neighboring state. Since the closest border of the next state is far away (about 50 $\mathrm{km}$ ), commuting of children seems to be less an option as well.

\section{Data}

\subsection{The Sample}

The empirical results are based on primary data obtained from a pen-and-paper survey that was administered to the 2007 Abitur class of 12 secondary schools. Ten of these schools are located in the city of Magdeburg (eight Gymnasium and two Integrierte Gesamtschule). Magdeburg (pop. 230,000) is located near the center of Saxony-Anhalt and is the state capital. For post-secondary education, it has a university, a university of applied sciences, and several research institutes. In addition, two schools (both Gymnasium) were sampled in Halberstadt. Halberstadt (county pop. 75,000 ) is a county town of a rural mountainous area, surrounded by villages and other smaller towns. The secondary schools are located in the larger population centers and a university of applied sciences is located in the area. All 12 schools are generic and can be considered representative for other public schools. 
The questionnaire consisted of 101 questions relating to various aspects of the student's personality, social background, and educational experiences. The survey was conducted during February, March and April of 2009. Finally, 805 responses were returned yielding a response rate of $55 \%$ of the questionnaires sent. In order to maintain consistency within the sample, only those students who were continuously enrolled in Germany during their complete schooling were included in the analysis; those students who took advantage of an exchange abroad, repeated or skipped a grade were excluded. This reduced the sample by 81 students, resulting in a final sample size of 724 individuals. The share of male students (37\%) is much smaller than that of female students $(63 \%)$. This finding is not a result of an imbalance in the response rates, but reflects a trend of higher female participation in university preparatory schooling that began in Germany more than a decade ago (destatis, 2009).

\subsection{Measures of Noncognitive Skills}

The prevailing view in the literature is that noncognitive skills are malleable beyond the age of twenty. Dahl (2004) highlights that the prefrontal cortex, the region of the brain that governs emotion and self-regulation, is susceptible up into the early twenties. Empirical evidence (see, e.g., Roberts et al., 2006, for an overview) reveals substantial mean-level changes at least until the age of 30. They invoke socio-environmental changes as one possible determinant. Abolishing a whole year of schooling results in a higher pressure at school and less time for extracurricular and leisure activities at an age when plasticity of personality traits could still be existent. Hence, the educational reform may have affected the students involved with regard to their personality development. In order to grasp the possible impact on various dimensions of the personality, appropriate measures have to be employed. Subsequently, we briefly introduce the set of measures we will incorporate in the empirical analysis below, and point out potential changes induced by the reform. Table 1 at the end of this section will summarize the measures and corresponding expectations of the reform effects. For some dimensions the expectations are ambiguous and therefore suggest possible trade-offs between home and school environment. The questions used in the survey to gather the personality facets are described in Appendix A.

As an overall measure of personality we employ a short version of the Big Five Inventory following Dehne and Schupp (2007). Compared to more comprehensive inventories, the abbreviated version is a very convenient tool in terms of large scale questionnaire assessments. The Big Five is a widely used measurement system which is based on a factor analytic approach exploiting lexical-linguistic information for a certain language. According to the denotation by Goldberg (1971), it incorporates the factors Openness to Experience, Conscientiousness, Extraversion, Agreeableness, and Neuroticism, which can be summarized in the acronym O.C.E.A.N. We orientate the following definition of the single factors on Hogan and Hogan (2007).

Conscientiousness, which describes the degree to which a person is willing to comply with conventional rules, norms, and standards, positively affects post-secondary academic achievements (O'Connor and Paunonen, 2007; Poropat, 2009). It also plays an important role with respect to other outcomes, 
e.g. labor force participation (Wichert and Pohlmeier, 2010). Extraversion refers to the individual's need for attention and social interaction, warmth, and gregariousness. As shown by Viinikainen et al. (2010) and Nandi and Nicoletti (2009) it is positively associated with earnings. Openness to Experience is related to an individual's need for intellectual stimulation, change, and variety. Facets are for example fantasy, curiosity, creativity, and unconventional ideas. Individuals with higher levels of Openness to Experience can be expected to prefer more creative and investigative occupations compared to individuals with lower levels. Empirical evidence suggest that Openness to Experience has also a positive effect on earnings (see, e.g. Braakmann, 2009; Nandi and Nicoletti, 2009). The factor Agreeableness broadly reflects the degree to which a person needs pleasant and harmonious relations with others. It is generally related to negative wage effects (see, e.g. Mueller and Plug, 2006; Braakmann, 2009; Wichert and Pohlmeier, 2010). The fifth factor, Neuroticism, describes the degree to which a person experiences the world as threatening and as something beyond its control. It comprises a range of factors like anxiety, depression, self-consciousness, and suffer from stress. Neuroticism has also been found to be associated with lower wages (see, e.g. Heineck and Anger, 2010).

As mentioned above, the Big Five inventory is quite a theoretical construct since it builds upon lexicallinguistic analyses and neglects the relatedness to potential outcomes. As a consequence, measures of the Big Five factors could exhibit only weak influence on certain outcomes though their sub-facets are highly relevant. In order to account for this fact, we will also consider further measures that are more content related, that is, they are validated by means of associated outcomes.

A measure commonly applied for these purposes is the Locus of Control (Rotter, 1966). It assesses an individual's attitude on how self-directed (internal) or how coincidental attainments in her or his life are. As opposed to concepts from motivational research (like Self-Efficacy), Locus of Control does not capture the beliefs in how successful one could be in governing its fate. Locus of Control is a major driving force with respect to educational attainments and wages (see, e.g. Heckman, Stixrud, and Urzua, 2006; Mueller and Plug, 2006; Braakmann, 2009). We use a 10-item version of the original Rotter scale. A further measure we apply is the Self-Control scale established by Tangney et al. (2004). Self-Control refers to the capability of adapting to environment due to controlling thoughts, emotions, impulses, and performance. Self-Control has positive effects on grades (Tangney et al., 2004, Duckworth and Seligman, 2005). Moreover, we use a measure originating from experimental economics: the Concept of Reciprocity introduced by Fehr and Gächter (2000). It explains cooperative behavior beyond interpretations by 'self-interest models'. Positive Reciprocity explains friendly response to friendly actions and, conversely, Negative Reciprocity refers to more nasty response to hostile actions. Dohmen et al. (2009) provide evidence that positively reciprocal people receive higher wages.

\subsection{Descriptive Statistics}

All personality attitudes gathered by the questionnaire are stated on 7-point Likert scales (1: "disagree completely" / "does not apply to me at all" to 7: "agree completely" / "applies to me perfectly"). Afterwards, the respective items are scored in one direction and standardized for the male and fe- 
Table 1: Measures and Anticipated Reform Effects

\begin{tabular}{|c|c|c|}
\hline Measure & Behavioral Facets & Anticipated Effect ${ }^{\mathrm{a}}$ \\
\hline Openness & $\begin{array}{l}\text { Need for intellectual stimulation, } \\
\text { change and variety (fantasy, } \\
\text { curiosity, creativity) }\end{array}$ & $\begin{array}{l}\text { (o) Higher requirements could enhance Openness whereas less } \\
\text { disposable time could decrease }\end{array}$ \\
\hline Conscientiousness & $\begin{array}{l}\text { Degree of willingness to comply with } \\
\text { conventional rules and norms }\end{array}$ & $(+)$ Increased intensity requires higher self-discipline and the like \\
\hline Extraversion & $\begin{array}{l}\text { Need for attention, social interaction } \\
\text { and gregariousness }\end{array}$ & (-) Less available time for social interaction \\
\hline Agreeableness & $\begin{array}{l}\text { Degree of demand for pleasant and } \\
\text { harmonious relation with others }\end{array}$ & $\begin{array}{l}\text { (o) Increased necessity for cooperation as well as more selfish } \\
\text { behavior could be induced }\end{array}$ \\
\hline Neuroticism & $\begin{array}{l}\text { Degree of perceiving the world as } \\
\text { something threatening that is } \\
\text { beyond personal control }\end{array}$ & $(+)$ Increased fear of failure \\
\hline Locus of Control (LOC) & $\begin{array}{l}\text { Attitude on how self-directed } \\
\text { (internal) or coincidental (external) } \\
\text { attainments in life are }^{b}\end{array}$ & $\begin{array}{l}\text { (o) Exogenous enactment of the reform could have decreased } \\
\text { LOC whereas recognizing the ability of coping with increased } \\
\text { requirements may have increased it }\end{array}$ \\
\hline Self-Control & $\begin{array}{l}\text { Capability of adapting to } \\
\text { environment by controlling } \\
\text { thoughts, emotions and performance }\end{array}$ & $\begin{array}{l}\text { (+) Increased requirements may raise necessity for higher } \\
\text { Self-Control }\end{array}$ \\
\hline $\begin{array}{l}\text { Positive/Negative } \\
\text { Reciprocity }\end{array}$ & $\begin{array}{l}\text { Friendly responses to friendly } \\
\text { actions/ hostile responses to hostile } \\
\text { actions }\end{array}$ & (o) Increased intensity could be an incentive for both \\
\hline
\end{tabular}

a $(+)$ positive, (-) negative and (o) ambiguous (positive/negative in terms of the score, not in terms of social desirability)

$\mathrm{b}$ As opposed to concepts from motivational research (like Self-Efficacy), LOC does not capture the beliefs in how successful one could be in governing its fate.

male sample. Internal consistency of the measures was checked by applying Cronbach's $\alpha$ (Cronbach, 1951), which relates average inter-item covariance to average item variance. The higher the $\alpha$, the more internally consistent is the measure. The obtained values are 0.77 (Self-Control), 0.75 (Negative Reciprocity) and 0.63 (Positive Reciprocity) and therefore indicate our scales to be adequate. The $\alpha$ for the Locus of Control, however, is saliently low (0.57). Nonetheless, we do not to drop this dimension since a possible systematic confounding will the intercept only, but does not affect the parameters of interest. Moreover, to assess the eligibility of the abbreviated Big Five inventory, we perform a Principal Component Analysis (PCA). The five factors explain about $65 \%$ of the variance and the factor loadings confirm the respective affiliations of the item triples.

Let us now turn to the characterization of the students before the reform took place. The related literature indicates that the family background and the parental investments are important ingredients for skill formation in general. Todd and Wolpin (2007) show that home items like number of books substantially contribute to cognitive skill formation. Cunha and Heckman (2008) reveal that cultural participation, like theater visits, is a strong predictor in terms of parental investments for cognitive and noncognitive skills. Another item employed by both studies is availability of a newspaper. We use three akin indicators, namely the "number of books" (measured in categorial dummies), whether the parents possess artifacts at home (dummy), and the availability of an internet access (dummy). Additionally, we use an "own TV" dummy. Besides the home resources, we use some general background variables which characterize the individual's situation during the whole cycle of schooling. These are subsumed in category schooltime family background (see Table 2). Mathematics and German grades at grade 7 were simply averaged in order to obtain a very general indicator of previous skill endowment. The dummy for family disruption equals one if one parent of the respondent has not been a member of the 
household for more than a year. The mean values are presented in Table 2. The variables show no differences between the treatment and control group of students; hence, there is no reason to expect any systematic differences in the outcomes due to the student's home environment.

Table 2: Means of Pre-Reform Background Characteristics by Gender for Treatment and Control Group

\begin{tabular}{|c|c|c|c|c|c|c|}
\hline & \multicolumn{3}{|c|}{ Male } & \multicolumn{3}{|c|}{ Female } \\
\hline & Grade 13 & Grade 12 & $p$-value ${ }^{\mathrm{a}}$ & Grade 13 & Grade 12 & $p$-value $^{\mathrm{a}}$ \\
\hline \multicolumn{7}{|l|}{ Schooltime family background } \\
\hline Age at enrollment & 6.227 & 6.223 & 0.951 & 6.189 & 6.115 & 0.050 \\
\hline No. of siblings & 0.922 & 1.014 & 0.402 & 0.940 & 0.904 & 0.649 \\
\hline Mother's age at birth & 25.429 & 25.927 & 0.290 & 25.616 & 26.055 & 0.316 \\
\hline Mother unemployed more than 1 year (D) & 0.141 & 0.201 & 0.190 & 0.127 & 0.124 & 0.944 \\
\hline Father unemployed more than 1 year (D) & 0.129 & 0.081 & 0.205 & 0.136 & 0.086 & 0.096 \\
\hline Math/German composite grade (at gr.7) ${ }^{\mathrm{b}}$ & 2.291 & 2.219 & 0.324 & 2.172 & 2.157 & 0.763 \\
\hline No. of moves & 1.656 & 1.604 & 0.771 & 1.638 & 1.627 & 0.939 \\
\hline Family disruption $(\mathrm{D})^{\mathrm{c}}$ & 0.307 & 0.194 & 0.033 & 0.322 & 0.250 & 0.091 \\
\hline Mother religious (D) & 0.203 & 0.209 & 0.912 & 0.133 & 0.168 & 0.296 \\
\hline Father religious (D) & 0.195 & 0.194 & 0.983 & 0.129 & 0.123 & 0.847 \\
\hline Mother leading position (D) & 0.270 & 0.206 & 0.225 & 0.231 & 0.207 & 0.541 \\
\hline Father leading postiton (D) & 0.309 & 0.348 & 0.504 & 0.350 & 0.338 & 0.802 \\
\hline \multicolumn{7}{|l|}{ Preschool background } \\
\hline Mother unemployed preschool age (D) & 0.031 & 0.079 & 0.090 & 0.074 & 0.060 & 0.547 \\
\hline Father unemployed preschool age (D) & 0.016 & 0.015 & 0.926 & 0.031 & 0.024 & 0.660 \\
\hline Day nursery (D) & 0.828 & 0.805 & 0.624 & 0.863 & 0.877 & 0.658 \\
\hline \multicolumn{7}{|l|}{ Home resources during schooltime } \\
\hline Own TV (D) & 0.703 & 0.734 & 0.579 & 0.760 & 0.691 & 0.101 \\
\hline Internet access (D) & 0.922 & 0.906 & 0.656 & 0.918 & 0.886 & 0.250 \\
\hline Artifacts at home (D) & 0.109 & 0.165 & 0.186 & 0.150 & 0.182 & 0.367 \\
\hline $50-250$ books $(D)^{\mathrm{d}}$ & 0.378 & 0.423 & & 0.349 & 0.393 & \\
\hline $250+$ books $(\mathrm{D})$ & 0.496 & 0.460 & 0.913 & 0.496 & 0.507 & 0.276 \\
\hline $\mathrm{N}$ & 128 & 139 & & 233 & 220 & \\
\hline
\end{tabular}

Dummy variables are indicated by (D).

${ }^{a} p$-value from $t$-test on equality of means. For the book dummies the p-values refer to the Chi-Square test.

b Mean of both grades. The best grade is 1.0 (very good), the worst is 6.0 (fail).

c At least one parent lives outside the household for longer than one year.

${ }^{\mathrm{d}}$ Group $0-50$ books is the baseline category.

The variables listed in Table 2 are likely to represent certain latent information. For instance, home providing items, like classic literature or artifacts, are assumed to represent parents who allocate more high quality skill investments to their child. With respect to the parental occupation, more than $30 \%$ of the fathers and more than $20 \%$ of the mothers work in a leading position. The percentages of parents who have been unemployed for at least a year range from about $8.5 \%$ to $20 \%$. Furthermore, the share of graduates who spent their childhood together with both parents is clearly below the societal average. According to the German Federal Bureau of Statistics, in 2010 on average, 25\% of the youth grew up in other forms of cohabitation than the traditional family. Religious engagement is reported for only a small fraction of parents. One reason for the limited religious engagement is due to the low rate of people who are affiliated with religious denominations in East Germany. In their 
preschool age between 80 and $90 \%$ of the graduates attended a kindergarten. ${ }^{3}$ In view of the fact that in Saxony-Anhalt the preschool system is ubiquitous, this finding is not surprising. Looking at the items available in the homes of the students shows that on average the households are well equipped. To summarize, we cannot find any systematic patterns of significant mean differences before the reform; for the vast majority of aspects, no differences between treatment and control group are given. This fosters the assumption of the natural experiment, and gaps in personality between both groups can be associated with the reform.

\section{Empirical Results}

\subsection{Estimation Strategy}

For the estimation of the effects of the increased learning intensity due to the educational reform on student's personality, we consider the nine personality facets introduced in section 3 as the outcome variables. By taking account of this variety of facets, especially the Big Five taxonomy, we intend to raise the validity of our results, since the reform is not expected to affect all dimensions in the same manner.

Given its implementation and supported by the descriptive comparison of treatment and control group before the reform took place, the educational reform fulfills the requirements of a natural experiment. Hence, we do not have to consider severe selection between treatment and control group regarding the observable and unobservable characteristics prior to the reform. Nevertheless, for the estimation of the treatment effect on personality the following aspects have to be regarded. First of all, since the sample under consideration stems from a set of 12 schools, school-related influences may play a role. Examples for these school-specific effects may be differences in the quality of teachers, differences in the infrastructure, differences in the number (and background) of the peers, or the composition of students overall. Therefore, to allow for an unbiased estimate of the reform effect including school-fixed effects is crucial as they capture all between-school variation. Moreover, it is likely that the development of personality differs by genders. To explicitly take account of potential gender differences in the effects, we will undertake separate estimations for male and female students.

The general specification of the individual estimation equation for each test score $T_{p, g}$ (refraining from indexing for individual) is given as follows:

$$
T_{p, g}=\alpha_{p, g}+\beta_{p, g} D+\mathbf{s}^{\prime} \gamma_{p, g}+\mathbf{x}^{\prime} \delta_{p, g}+\varepsilon_{p, g}
$$

where $p$ indexes the personality dimensions under study and $g$ refers to the individual's gender. The intercept is $\alpha_{p, g}$. Furthermore, $D$ is the treatment dummy with $\beta_{p, g}$ as the primary parameter of interest, $\mathbf{s}$ controls for school-fixed effects and $\mathbf{x}$ are further background variables included in the models. $\gamma_{p, g}$ and $\delta_{p, g}$ are the corresponding coefficient vectors.

\footnotetext{
3 In Germany, kindergarten attendance is not mandatory. Mandatory schooling starts at elementary school.
} 
As outlined in the theoretical model above, the treatment effect of the increased learning intensity on the personality does not solely result from the difference in schooling inputs, but also from differences in extracurricular activities. However, as mentioned above, we assume a trade-off in time for students with regard to these two types of investments and, therefore, observable differences are a result of the reform. With respect to our notation in section 2.2 this means, that $\beta_{p, g}$ is a function of $\boldsymbol{I}_{t-1, S}$ and $\boldsymbol{I}_{t-1, H}$ :

$$
E\left(T_{p, g}^{G 12}-T_{p, g}^{G 13}\right)=\beta_{p, g}\left(\boldsymbol{I}_{t-1, S}, \boldsymbol{I}_{t-1, H}\right)
$$

Though information on the disposable leisure as an indicator for extracurricular activities is available in the data, accounting for this information in eq. (2) is difficult since the causal relationship between the choice of leisure and personality expression is ambiguous. As a consequence, OLS estimates would be biased. Due to a lack of reliable instruments, estimating simultaneous equations is also infeasible. Therefore, we will conduct a separate estimation for a potential treatment effect on disposable leisure assuming independence of errors. This will be subject to the robustness checks in section 4.3.

Moreover, the questionnaire contains a lot of information on the students' childhood and parental influences. Therefore, we can utilize this information to proxy prior investments, that presumably have constituted the stock of noncognitive skills. If the assumption of a natural experiment is valid, no significant variations in the treatment parameter should be induced by including further background variables or different specifications of these background variables. Instead, selecting the appropriate model increases the precision of the estimates. We choose the superior model specification based on F-tests for the included blocks and the Akaike Information Criterion (Akaike, 1973). We tested four different specifications along the background variables illustrated in Table 2. The first specification accounts for family background throughout the complete cycle of schooling until the reform was imposed, like number of siblings or parental employment. The second specification augments this information by variables characterizing the family background during preschool age (employment status and whether the respondent visited a day nursery), whereas the third uses additional information on home resources during the schooling years prior to the reform (own TV, internet access, artifacts at home, and number of books). The fourth specification considers all these background variables.

The estimated effects can also be attenuated if substantial accommodations were conducted to make the reform more convenient. In order to weaken this possibility, we examined additional information gathered by the questionnaire which refers to statements about perceived stress and mental balance. Checking for the effects of the reform on these variables (results are not displayed here), we found a statistically significant increase in perceived stress and a decrease in mental balance for the G12 cohort compared to G13. This result does not completely rule out the possibility that we observe and measure a somewhat narrower policy change, but it proves that adaptions were rather minor.

Finally, related to the school effects, we have to consider the class-level clustering of the sampled students in the estimation. Since students in the sample come from a distinct number of classes within schools, there may be some correlation of in-class outcomes. For this reason, the cluster-robust sandwich estimator suggested by White (1980) is employed. The number of clusters is sufficiently high 
(above 80) for all models estimated so that consistency of the variance estimates is presumed.

\subsection{Estimation Results}

\section{Reform Effects}

Let us start the discussion of the empirical estimates with the interpretation of the reform effects. The corresponding estimation results are provided in Table 3 for the measures of the Big Five and in Table 4 for the four other measures considered, separately for both genders. Since we use standardized personality measures in the regressions, the slope parameters have to be interpreted in terms of standard deviations. For better interpretation of the magnitudes, Appendix B provides Kernel densities of all examined personality measures. All estimations of treatment effects take account of school-fixed effects and further background variables. The chosen specifications of these background variables vary across models in order to provide efficient estimates.

The estimates show, that increasing the learning intensity by about $20 \%$ has no sizable impact on any of the facets considered. Neither for males nor for females the noncognitive skills are affected by the substantial increase of learning intensity in late adolescence. With regard to the potential modes of operation as introduced in section 2.2, there can be several explanations for these findings. First and foremost, it is likely that the induced changes in inputs are too minor in order to affect personality development at this age (see Cunha and Heckman, 2006); this interpretation is in line with previous empirical results (see, e.g., Cunha et al., 2010). Alternatively, one can suppose a potential compensation of the two types of investments, i.e. the effect of the increased curricular activities, on the one hand, and that of the decreased extracurricular activities, on the other hand, equal out. However, this explanation is less plausible in our opinion. If compensation of two opposing effects were the case, the picture of the treatment effects of the different personality facets regarded would probably be less homogeneous. This is due to the fact, that schooling can be expected to affect other dimensions of personality than extracurricular activities do.

Hence, the impact of the analyzed educational policy reform on noncognitive skills differs from the effect on grade achievements. Whereas higher learning intensity affects student academic achievement negatively (see Büttner and Thomsen, 2010), student's personality remains unaffected. Therefore, the consensus view that higher academic requirements at school come at the expense of an impeded personality development cannot be supported. The findings presented here indicate, that the development of students' personality copes well with the increased learning intensity. 
Table 3: Regression Estimates: Big Five (Gender Specific)*

\begin{tabular}{|c|c|c|c|c|c|c|c|c|c|c|}
\hline & \multicolumn{2}{|c|}{ Openn. } & \multicolumn{2}{|c|}{ Consc. } & \multicolumn{2}{|c|}{ Extrav. } & \multicolumn{2}{|c|}{ Agreea. } & \multicolumn{2}{|c|}{ Neurot. } \\
\hline & $(\mathrm{m})$ & (f) & $(\mathrm{m})$ & (f) & $(\mathrm{m})$ & (f) & $(\mathrm{m})$ & (f) & $(\mathrm{m})$ & (f) \\
\hline Treatment Effect & $\begin{array}{r}0.087 \\
(0.112)\end{array}$ & $\begin{array}{r}-0.020 \\
(0.097)\end{array}$ & $\begin{array}{r}0.120 \\
(0.148)\end{array}$ & $\begin{array}{r}-0.142 \\
(0.094)\end{array}$ & $\begin{array}{r}-0.016 \\
(0.130)\end{array}$ & $\begin{array}{r}0.141 \\
(0.102)\end{array}$ & $\begin{array}{r}0.005 \\
(0.128)\end{array}$ & $\begin{array}{r}0.091 \\
(0.087)\end{array}$ & $\begin{array}{r}-0.182 \\
(0.135)\end{array}$ & $\begin{array}{r}-0.156 \\
(0.094)\end{array}$ \\
\hline \multicolumn{11}{|c|}{ Schooltime family background } \\
\hline Age at enrollment & $\begin{array}{r}-0.054 \\
(0.132)\end{array}$ & $\begin{array}{r}-0.023 \\
(0.118)\end{array}$ & $\begin{array}{r}-0.128 \\
(0.147)\end{array}$ & $\begin{array}{c}0.192^{*} \\
(0.113)\end{array}$ & $\begin{array}{r}0.103 \\
(0.162)\end{array}$ & $\begin{array}{r}0.162 \\
(0.109)\end{array}$ & $\begin{array}{r}-0.016 \\
(0.143)\end{array}$ & $\begin{array}{r}0.094 \\
(0.123)\end{array}$ & $\begin{array}{r}-0.173 \\
(0.152)\end{array}$ & $\begin{array}{r}0.171 \\
(0.129)\end{array}$ \\
\hline No. of siblings & $\begin{array}{r}-0.115 \\
(0.076)\end{array}$ & $\begin{array}{r}0.014 \\
(0.072)\end{array}$ & $\begin{array}{r}0.026 \\
(0.073)\end{array}$ & $\begin{array}{r}0.025 \\
(0.064)\end{array}$ & $\begin{array}{r}-0.121 \\
(0.076)\end{array}$ & $\begin{array}{l}0.146^{* *} \\
(0.060)\end{array}$ & $\begin{array}{r}0.067 \\
(0.093)\end{array}$ & $\begin{array}{r}0.049 \\
(0.052)\end{array}$ & $\begin{array}{r}0.021 \\
(0.075)\end{array}$ & $\begin{array}{r}-0.046 \\
(0.060)\end{array}$ \\
\hline Mother's age at birth & $\begin{array}{r}0.014 \\
(0.020)\end{array}$ & $\begin{array}{r}-0.008 \\
(0.011)\end{array}$ & $\begin{array}{r}-0.023 \\
(0.016)\end{array}$ & $\begin{array}{r}0.007 \\
(0.013)\end{array}$ & $\begin{array}{r}-0.008 \\
(0.020)\end{array}$ & $\begin{array}{r}-0.019 \\
(0.013)\end{array}$ & $\begin{array}{r}0.029 \\
(0.018)\end{array}$ & $\begin{array}{r}0.007 \\
(0.012)\end{array}$ & $\begin{array}{l}-0.035^{*} \\
(0.019)\end{array}$ & $\begin{array}{r}0.001 \\
(0.012)\end{array}$ \\
\hline $\begin{array}{l}\text { Mother's unemployment } \\
\text { spell (months) }\end{array}$ & $\begin{array}{l}-0.373^{* *} \\
(0.157)\end{array}$ & $\begin{array}{r}0.265 \\
(0.160)\end{array}$ & $\begin{array}{r}0.306 \\
(0.195)\end{array}$ & $\begin{array}{r}-0.184 \\
(0.140)\end{array}$ & $\begin{array}{r}-0.135 \\
(0.222)\end{array}$ & $\begin{array}{r}0.116 \\
(0.155)\end{array}$ & $\begin{array}{r}-0.082 \\
(0.185)\end{array}$ & $\begin{array}{r}-0.006 \\
(0.149)\end{array}$ & $\begin{array}{r}-0.009 \\
(0.140)\end{array}$ & $\begin{array}{l}0.311^{*} \\
(0.161)\end{array}$ \\
\hline $\begin{array}{l}\text { Father's unemployment } \\
\text { spell (months) }\end{array}$ & $\begin{array}{r}-0.073 \\
(0.250)\end{array}$ & $\begin{array}{r}0.209 \\
(0.174)\end{array}$ & $\begin{array}{l}-0.535^{* *} \\
(0.239)\end{array}$ & $\begin{array}{r}-0.116 \\
(0.165)\end{array}$ & $\begin{array}{r}-0.182 \\
(0.243)\end{array}$ & $\begin{array}{r}-0.160 \\
(0.146)\end{array}$ & $\begin{array}{r}-0.020 \\
(0.211)\end{array}$ & $\begin{array}{l}-0.296^{*} \\
(0.164)\end{array}$ & $\begin{array}{r}0.292 \\
(0.185)\end{array}$ & $\begin{array}{r}-0.211 \\
(0.177)\end{array}$ \\
\hline $\begin{array}{l}\text { Math/German composite } \\
\text { grade (at gr.7) }\end{array}$ & $\begin{array}{r}-0.002 \\
(0.123)\end{array}$ & $\begin{array}{r}-0.095 \\
(0.085)\end{array}$ & $\begin{array}{r}-0.016 \\
(0.118)\end{array}$ & $\begin{array}{l}-0.157^{*} \\
(0.094)\end{array}$ & $\begin{array}{r}0.093 \\
(0.109)\end{array}$ & $\begin{array}{r}-0.008 \\
(0.092)\end{array}$ & $\begin{array}{r}0.008 \\
(0.107)\end{array}$ & $\begin{array}{r}-0.144 \\
(0.092)\end{array}$ & $\begin{array}{r}-0.011 \\
(0.110)\end{array}$ & $\begin{array}{r}0.038 \\
(0.091)\end{array}$ \\
\hline No. of moves & $\begin{array}{r}0.047 \\
(0.162)\end{array}$ & $\begin{array}{r}-0.028 \\
(0.116)\end{array}$ & $\begin{array}{r}0.104 \\
(0.193)\end{array}$ & $\begin{array}{r}-0.155 \\
(0.119)\end{array}$ & $\begin{array}{r}0.031 \\
(0.216)\end{array}$ & $\begin{array}{r}-0.040 \\
(0.127)\end{array}$ & $\begin{array}{r}0.152 \\
(0.172)\end{array}$ & $\begin{array}{r}-0.053 \\
(0.119)\end{array}$ & $\begin{array}{r}-0.199 \\
(0.161)\end{array}$ & $\begin{array}{r}-0.060 \\
(0.121)\end{array}$ \\
\hline Family disruption $(\mathrm{D})^{\mathrm{b}}$ & $\begin{array}{l}0.129 * * \\
(0.050)\end{array}$ & $\begin{array}{r}0.048 \\
(0.036)\end{array}$ & $\begin{array}{r}-0.046 \\
(0.060)\end{array}$ & $\begin{array}{r}-0.042 \\
(0.033)\end{array}$ & $\begin{array}{r}0.000 \\
(0.053)\end{array}$ & $\begin{array}{r}0.021 \\
(0.039)\end{array}$ & $\begin{array}{r}-0.001 \\
(0.053)\end{array}$ & $\begin{array}{r}-0.050 \\
(0.041)\end{array}$ & $\begin{array}{r}0.053 \\
(0.052)\end{array}$ & $\begin{array}{r}0.064 \\
(0.041)\end{array}$ \\
\hline Mother religious (D) & $\begin{array}{r}0.240 \\
(0.255)\end{array}$ & $\begin{array}{l}0.280^{* *} \\
(0.139)\end{array}$ & $\begin{array}{r}-0.112 \\
(0.179)\end{array}$ & $\begin{array}{r}-0.038 \\
(0.162)\end{array}$ & $\begin{array}{l}0.375^{*} \\
(0.208)\end{array}$ & $\begin{array}{r}-0.026 \\
(0.148)\end{array}$ & $\begin{array}{r}-0.312 \\
(0.196)\end{array}$ & $\begin{array}{r}-0.232 \\
(0.154)\end{array}$ & $\begin{array}{r}0.404 \\
(0.261)\end{array}$ & $\begin{array}{l}-0.286^{*} \\
(0.155)\end{array}$ \\
\hline Father religious (D) & $\begin{array}{r}0.037 \\
(0.218)\end{array}$ & $\begin{array}{r}-0.137 \\
(0.198)\end{array}$ & $\begin{array}{l}-0.456^{* *} \\
(0.183)\end{array}$ & $\begin{array}{l}-0.354^{*} \\
(0.207)\end{array}$ & $\begin{array}{r}-0.184 \\
(0.215)\end{array}$ & $\begin{array}{r}-0.116 \\
(0.208)\end{array}$ & $\begin{array}{l}0.373^{* *} \\
(0.181)\end{array}$ & $\begin{array}{r}-0.177 \\
(0.200)\end{array}$ & $\begin{array}{r}-0.239 \\
(0.271)\end{array}$ & $\begin{array}{l}0.276^{*} \\
(0.165)\end{array}$ \\
\hline $\begin{array}{l}\text { Mother leading position } \\
\text { (D) }\end{array}$ & $\begin{array}{r}-0.236 \\
(0.153)\end{array}$ & $\begin{array}{r}0.048 \\
(0.126)\end{array}$ & $\begin{array}{r}0.214 \\
(0.149)\end{array}$ & $\begin{array}{r}-0.017 \\
(0.125)\end{array}$ & $\begin{array}{r}-0.202 \\
(0.172)\end{array}$ & $\begin{array}{r}0.211 \\
(0.133)\end{array}$ & $\begin{array}{r}-0.054 \\
(0.159)\end{array}$ & $\begin{array}{r}-0.065 \\
(0.086)\end{array}$ & $\begin{array}{l}-0.328^{* *} \\
(0.149)\end{array}$ & $\begin{array}{r}-0.077 \\
(0.117)\end{array}$ \\
\hline $\begin{array}{l}\text { Father leading position } \\
\text { (D) }\end{array}$ & $\begin{array}{r}0.108 \\
(0.121) \\
\end{array}$ & $\begin{array}{r}0.127 \\
(0.105) \\
\end{array}$ & $\begin{array}{r}0.153 \\
(0.149) \\
\end{array}$ & $\begin{array}{r}0.085 \\
(0.103) \\
\end{array}$ & $\begin{array}{r}0.236 \\
(0.152) \\
\end{array}$ & $\begin{array}{r}0.119 \\
(0.103) \\
\end{array}$ & $\begin{array}{r}-0.018 \\
(0.143) \\
\end{array}$ & $\begin{array}{r}0.039 \\
(0.098) \\
\end{array}$ & $\begin{array}{r}-0.038 \\
(0.136) \\
\end{array}$ & $\begin{array}{r}-0.051 \\
(0.118) \\
\end{array}$ \\
\hline \multicolumn{11}{|l|}{ Preschool background } \\
\hline $\begin{array}{l}\text { Mother unemployed } \\
\text { preschool age (D) }\end{array}$ & $\begin{array}{l}0.609^{* *} \\
(0.232)\end{array}$ & $\begin{array}{c}0.335^{*} \\
(0.192)\end{array}$ & $\begin{array}{l}-0.714^{* *} \\
(0.334)\end{array}$ & $\begin{array}{l}- \\
-\end{array}$ & $\begin{array}{c}0.315^{*} \\
(0.170)\end{array}$ & $\begin{array}{r}0.093 \\
(0.265)\end{array}$ & $\begin{array}{l}- \\
-\end{array}$ & $\begin{array}{l}- \\
-\end{array}$ & $\begin{array}{l}- \\
-\end{array}$ & $\begin{array}{l}-0.624^{* * *} \\
(0.184)\end{array}$ \\
\hline $\begin{array}{l}\text { Father unemployed } \\
\text { preschool age (D) }\end{array}$ & $\begin{array}{r}0.100 \\
(0.253)\end{array}$ & $\begin{array}{r}-0.252 \\
(0.332)\end{array}$ & $\begin{array}{r}-0.323 \\
(0.308)\end{array}$ & - & $\begin{array}{r}0.437 \\
(0.461)\end{array}$ & $\begin{array}{l}-0.553^{* *} \\
(0.235)\end{array}$ & - & - & - & $\begin{array}{r}0.166 \\
(0.301)\end{array}$ \\
\hline Day nursery (D) & $\begin{array}{r}0.001 \\
(0.171) \\
\end{array}$ & $\begin{array}{r}0.127 \\
(0.156) \\
\end{array}$ & $\begin{array}{r}-0.189 \\
(0.195) \\
\end{array}$ & $\begin{array}{l}- \\
- \\
\end{array}$ & $\begin{array}{r}-0.071 \\
(0.171) \\
\end{array}$ & $\begin{array}{r}-0.208 \\
(0.178) \\
\end{array}$ & $\begin{array}{l}- \\
- \\
\end{array}$ & $\begin{array}{l}- \\
- \\
\end{array}$ & $\begin{array}{l}- \\
- \\
\end{array}$ & $\begin{array}{r}-0.163 \\
(0.206) \\
\end{array}$ \\
\hline \multicolumn{11}{|c|}{ Home resources during schooltime } \\
\hline Own TV (D) & $\begin{array}{c}-0.273^{*} \\
(0.146)\end{array}$ & $\begin{array}{r}-0.035 \\
(0.133)\end{array}$ & $\begin{array}{l}- \\
-\end{array}$ & $\begin{array}{r}0.127 \\
(0.114)\end{array}$ & $\begin{array}{r}0.071 \\
(0.184)\end{array}$ & $\begin{array}{l}- \\
-\end{array}$ & $\begin{array}{l}- \\
-\end{array}$ & $\begin{array}{l}- \\
-\end{array}$ & $\begin{array}{l}- \\
- \\
-\end{array}$ & $\begin{array}{r}0.002 \\
(0.120)\end{array}$ \\
\hline Internet access (D) & $\begin{array}{r}-0.114 \\
(0.212)\end{array}$ & $\begin{array}{r}-0.000 \\
(0.171)\end{array}$ & $\begin{array}{l}- \\
- \\
-\end{array}$ & $\begin{array}{l}-0.304^{* *} \\
(0.130)\end{array}$ & $\begin{array}{c}0.500^{*} \\
(0.261)\end{array}$ & $\begin{array}{l}- \\
-\end{array}$ & - & - & $\begin{array}{l}- \\
-\end{array}$ & $\begin{array}{r}-0.107 \\
(0.171)\end{array}$ \\
\hline Artifacts at home (D) & $\begin{array}{l}0.395^{* * *} \\
(0.126)\end{array}$ & $\begin{array}{l}0.311^{* * *} \\
(0.095)\end{array}$ & - & $\begin{array}{r}-0.018 \\
(0.110)\end{array}$ & $\begin{array}{r}0.220 \\
(0.134)\end{array}$ & - & - & - & - & $\begin{array}{l}-0.200^{* *} \\
(0.096)\end{array}$ \\
\hline $50-250$ books $(\mathrm{D})^{\mathrm{c}}$ & $\begin{array}{r}0.005 \\
(0.235)\end{array}$ & $\begin{array}{r}0.137 \\
(0.163)\end{array}$ & - & $\begin{array}{r}0.211 \\
(0.177)\end{array}$ & $\begin{array}{r}-0.280 \\
(0.247)\end{array}$ & - & - & - & $\begin{array}{l}- \\
-\end{array}$ & $\begin{array}{r}0.117 \\
(0.181)\end{array}$ \\
\hline $250+$ books (D) & $\begin{array}{r}0.299 \\
(0.228)\end{array}$ & $\begin{array}{c}0.316^{* *} \\
(0.158)\end{array}$ & $\begin{array}{l}- \\
- \\
-\end{array}$ & $\begin{array}{r}-0.040 \\
(0.172)\end{array}$ & $\begin{array}{l}-0.482^{*} \\
(0.251)\end{array}$ & $\begin{array}{l}- \\
- \\
-\end{array}$ & $\begin{array}{l}- \\
- \\
-\end{array}$ & $\begin{array}{l}- \\
- \\
-\end{array}$ & $\begin{array}{l}- \\
- \\
-\end{array}$ & $\begin{array}{r}0.079 \\
(0.163)\end{array}$ \\
\hline Cons. & -0.143 & 0.055 & 1.632 & -0.722 & -0.725 & -0.762 & -0.529 & -0.053 & $2.329^{* *}$ & -0.898 \\
\hline$\overline{\mathrm{R}^{2}}$ & 0.269 & 0.132 & 0.135 & 0.094 & 0.127 & 0.082 & 0.089 & 0.064 & 0.114 & 0.100 \\
\hline $\mathrm{N}$ & 236 & 402 & 240 & 403 & 237 & 404 & 244 & 405 & 244 & 404 \\
\hline No. of Clusters & 82 & 86 & 82 & 86 & 82 & 86 & 82 & 86 & 82 & 86 \\
\hline
\end{tabular}

(m)-male, (f)-female. Dummy variables are indicated by (D).

OLS estimates for regression of standardized personality measures on treatment dummy, school-fixed effects and further background variables. Coefficient estimates of school-fixed effects are skipped from display. Model selection is based on $F$-tests and Akaike Information Criterion (Akaike, 1973)

Standard errors in parentheses. All standard errors are clustering-robust (see White, 1980) based on class as the sampling unit.

Standard errors in parentheses. All

${ }^{a}$ Mean of both grades. The best grade is 1.0 (very good), the worst is 6.0 (fail).

$\mathrm{b}$ At least one parent lives outside the household for longer than one year.

${ }^{\mathrm{c}}$ Group $0-50$ books is the baseline category. 
Table 4: Regression Estimates: Locus of Control, Self-Control, Positve/Negative Reciprocity (Gender Specific) ${ }^{*}$



\section{Effects of Background Characteristics}

Besides the evaluation of the impact on the various personality measures, the estimation results offer a range of insights into the influences of the incorporated background variables (see Tables 3 and 4 for the corresponding coefficient estimates). Particularly, for the period of later adolescence the empirical literature on the determinants of noncognitive skills is rather scarce. For instance, the panel used by Cunha, Heckman, and Schennach (2010) is more detailed in terms of family investments and allows to account for dynamics in personality development, but ends at age 14. Since the aim of testing different model specifications was to raise the precision of the estimates, only the results for the superior models will be discussed. Hence, the background variables included in the models may differ across outcomes 
and genders.

Big Five Inventory: Family disruption increases Openness to Experience of males by 0.13 standard deviations. This finding may indicate a raise in the autonomy of the child. Unemployment of the mother has a positive impact (0.61) if it took place in preschool age, but a negative one (-0.38) in case of unemployment spell at later ages. A possible explanation is that generally a mother spends a lot of time for nurture in the child's early years, whereas in later years unemployment is solely associated with financial drawbacks negatively affecting the child's development. The picture for female offsprings is comparable, but less significant. Furthermore, a religious mother raises the degree of openness stated by female respondents by 0.27 standard deviations. Children, whose parents possess some artifacts are on average endowed with a 0.31 (females) to 0.40 (males) standard deviations higher score of Openness. Having a lot of books at home has the same effect, but only in case of females. These results are in line with the findings by Cunha and Heckman (2008), which state that parents strongly devoted to cultural activities positively influence their children's personality.

In case of Conscientiousness, fathers' experiencing unemployment during schooling age of the child as well as religiousness decrease the score by about half a standard deviation. Since the father may be a kind of role model, unemployment and religiousness may determine how far their sons comply with conventional rules etc. Unemployment of mother in preschool age even shrinks the score by 0.71 standard deviations. Possibly Conscientiousness is a trait less promoted by dedication, but by setting an example with respect to the way of living. For females the effects are only weakly significant except for having an internet access (-0.30). This result seems intuitively plausible when considering the role of the internet in the formation of opinions.

For male students there is only weak significance in explaining variations in the degree of Extraversion. Females are only slightly positively affected by the number of siblings (0.15). Probably, a high degree of Extraversion is necessary in order to obtain sufficient attention within the family environment. The regression results for Agreeableness are hardly significant, too. Only religiousness of the father has a substantial positive effect (0.37). Again, this result is probably linked to the kind of rearing the child experiences.

Males whose mothers possess a leading occupational position are more neurotic (-0.33). This finding is rather surprising. The aforementioned argument that mothers dedicating a large amount of time for rearing activities in their offspring's preschool age positively influence its development is supported by the effect of the unemployment dummy for mothers. For those female respondents, whose mothers were unemployed in their preschool age, the Neuroticism score decreases by 0.62 standard deviations. Again, the presence of artifacts at home seems to be an indicator for a higher quality parenting (-0.20).

Locus of Control: The occupational position of the mother seems to have an impact on how internal the students are. If the mother possess a leading position at work, the Locus of Control increases by about 0.27 (females) and 0.34 (males) standard deviations. For the male sample, the remaining effects 
are mostly insignificant. In case of females, the number of moves apparently inhibits the believe, that their life and destiny is not influenced by their own doing (-0.19). Religiousness of fathers appears to cause their daughters to perceive their fortune to be more externally driven $(-0.40)$. The presence of more than 250 books at home affects the internal control score of female students negatively by 0.30 standard deviations.

Self-Control: The degree of Self-Control cannot be explained by our control variables in case of male students. For females, a higher occupational position of the father as well as religiousness of the mother increase Self-Control by 0.20 and 0.33 standard deviations. As opposed to this, the religiousness of the father and family disruption negatively influence the scores for the female sample $(-0.43$ and -0.09). The different impacts of religiousness are difficult to interpret. However, the influence of the occupational position of the father seems to be another hint for the existence of a certain role model pattern. Likewise straightforward is the interpretation that children rearing in a disrupted family environment are less self-disciplined and more impulsive.

Positive Reciprocity: For male students the parameter estimates of the background variables are not significant. We only observe a weakly significant, negative impact of the average schooling grade of year seven and of mother's occupational position for female students. Since schooling grades in Germany are rated inversely (grade 1 refers to excellent, grade 6 to failure), female students with worse grades are less positively reciprocal, maybe due to enviousness. Therefore, descending from a more educated has the same positive effect, since possessing more than 250 books raises Positive Reciprocity by 0.36 standard deviations.

Negative Reciprocity: The coefficient estimates of the background variables for Negative Reciprocity are similar to those for Positive Reciprocity. The artifact's item reduces Negative Reciprocity by 0.30 standard deviations in case of males, but shows only weak significance. Moreover, mothers' overall unemployment spell throughout the schooltime reduces its expression in the child substantially by 0.47 standard deviations. The Negative Reciprocity score in the female sample is higher if they were enrolled at a later age. Possibly this observation is induced by certain peer group effects. Intuitively reasonable, religiousness of the mother decreases the score. In addition, we observe a strongly negative effect of an unemployed father in early childhood on the score. This result is rather surprisingly and has no meaningful interpretation. Interestingly, the attendance of a day nursery before school-age decreases Negative Reciprocity by half a standard deviation, which is likely to be related to the important role of social interaction highlighted in the literature (see, e.g., Cunha and Heckman, 2009). 


\subsection{Robustness Checks}

Although the regression models of the treatment effect of the reform did not establish significant effects for any of the personality measures considered, there may be concerns about the robustness of the estimates. A first concern may be related to the role of possible age effects confounding the estimated treatment effect. A second concern relates to the potential trade-off effects, overlying the reform effect for the students in consideration. The former concern is put forward by the fact that students differed in age, when the reform was imposed by on average a full year, whereas the latter refers to the potential trade-off between schooling and extracurricular investments.

To identify the sole effect of age on the development of noncognitive skills, we have estimated separate models within both cohorts using the boundaries of the age distribution. As before, we conducted these estimations separately by gender. All in all, we used four subsamples: females in G12, females in G13, males in G12, and males in G13. These subsamples contained only those students, who were born in the first three months and in the last three months of the respective cohort. Relying on birth quarters is sensible in order to obtain sufficiently high numbers of clusters to raise the efficiency of the cluster-robust sandwich estimator of the variance used in the estimation. Subsequently, we regressed all personality measures on the baseline specification as used before and included an additional dummy variable taking the value 1 if the student was born during the first three months (i.e., for the elder students) and 0 if the student was born during the last three months of the stretch. The corresponding coefficient estimates of this dummy variable are presented in Table 5.

Apart from the Openness to Experience score for male G12 students, there are no significant age effects. This finding remained robust in level and significance independently of the specification of the further background variables included, as further specification checks indicated (not displayed here). Though the number of available observations and clusters seems sufficiently large to warrant consistent variance estimates, we additionally checked the age pattern for a larger sample (539 males/ 572 females) taken from German Socio-Economic Panel Study (GSOEP) respondents within the complete age span of the G12 and G13 cohorts. ${ }^{4}$ Except for self-control, the 2005 wave of the GSOEP comprises the same personality measures we used. Hence, we have regressed the standardized personality measures on age and various combinations of background variables (replicating the analysis' sample as good as possible). The age effects are invariant to the tested model specification but a parsimonious specification retains the highest number of observations. Therefore, Table 6 only illustrates the the coefficients for the model specification with age as the only regressor.

$4 \quad$ The sample contains graduates from all types of schooling in this age interval and is not restricted to graduates from higher secondary schooling. 
Table 5: Age Effects ${ }^{\mathrm{a}}$

\begin{tabular}{lrrrr}
\hline \hline & \multicolumn{3}{c}{ (male) } & \multicolumn{2}{c}{ (female) } \\
& G13 & G12 & G13 & G12 \\
\hline Locus of Control & 0.189 & -0.063 & -0.039 & 0.068 \\
& $(0.413)$ & $(0.372)$ & $(0.386)$ & $(0.302)$ \\
\hline Self-Control & -0.115 & 0.519 & -0.170 & 0.056 \\
& $(0.362)$ & $(0.537)$ & $(0.235)$ & $(0.232)$ \\
\hline Positive Reciprocity & -0.069 & -0.343 & -0.299 & -0.009 \\
Negative Reciprocity & $(0.500)$ & $(0.408)$ & $(0.376)$ & $(0.283)$ \\
& 0.153 & 0.588 & -0.483 & -0.155 \\
Openness to Experience & $(0.407)$ & $(0.384)$ & $(0.291)$ & $(0.331)$ \\
& 0.075 & $0.741 *$ & 0.020 & 0.076 \\
Conscientiousness & $(0.478)$ & $(0.367)$ & $(0.230)$ & $(0.267)$ \\
& -0.326 & -0.037 & 0.106 & -0.217 \\
Extraversion & $(0.438)$ & $(0.515)$ & $(0.259)$ & $(0.247)$ \\
Agreeableness & 0.409 & 0.227 & 0.039 & -0.007 \\
& $(0.558)$ & $(0.400)$ & $(0.283)$ & $(0.266)$ \\
Neuroticism & -0.269 & -0.684 & 0.156 & 0.077 \\
& $(0.446)$ & $(0.481)$ & $(0.207)$ & $(0.193)$ \\
\hline \hline
\end{tabular}

${ }^{a}$ G12: 12 year graduates; G13: 13 year graduates.

OLS estimates for regressions of standardized personality measures on age dummy within subsamples (male/G13, male/G12, female/G13, female/G12). The age dummy equals 1 if the student is born during the the first three months and 0 if the student is born during the last three of the birth stretch in the cohort. Further variables included cover further background variables as used in the specifications displayed in Tables 3 and 4 and the school-fixed effects. Coefficient estimates of these variables are skipped from display.

Standard errors in parentheses. All standard errors are clustering-robust (see White, 1980) based on class as the sampling unit.

${ }^{*} p<0.1,{ }^{* *} p<0.05,{ }^{* * *} p<0.01$

Table 6: Age Effects for GSOEP sample

\begin{tabular}{lcc}
\hline \hline & (male) & $($ female $)$ \\
\hline Locus of Control & 0.043 & -0.033 \\
& $(0.039)$ & $(0.034)$ \\
\hline Positive Reciprocity & 0.041 & -0.004 \\
& $(0.038)$ & $(0.037)$ \\
Negative Reciprocity & -0.003 & -0.005 \\
& $(0.038)$ & $(0.035)$ \\
\hline Openness to Experience & 0.031 & -0.016 \\
& $(0.037)$ & $(0.035)$ \\
Conscientiousness & $0.133^{* * *}$ & -0.033 \\
& $(0.041)$ & $(0.041)$ \\
Extraversion & -0.011 & 0.023 \\
& $(0.041)$ & $(0.038)$ \\
Agreeableness & 0.023 & -0.000 \\
& $(0.039)$ & $(0.036)$ \\
Neuroticism & 0.054 & 0.012 \\
& $(0.037)$ & $(0.036)$ \\
\hline \hline
\end{tabular}

${ }^{*} p<0.1,{ }^{* *} p<0.05,{ }^{* * *} p<0.01$ (Standard errors in parentheses)

The sample for males includes 539 observations, the sample for females 572 .

Apart from Conscientiousness for males we can rule out potential age effects to affect our previous estimation results. The result for Conscientiousness, though not strong in magnitude, can be interpreted as a consequence of enduring shifts in social roles and role expectations after graduation from school. According to Roberts, Viechtbauer, and Walton (2006) such a change is likely to be at hand 
when entering into employment for the first time, particularly for traits associated with thorough working. Especially those young adults in our GSOEP sample from lower educational tracks already have finished schooling for a considerable time. We therefore assume that the observed pattern for Conscientiousness is rather due to the specific properties of this transition period in conjecture with sample composition. Since a similar effect is not apparent for the other personality traits, an opposed age effect that may have caused the insignificance of the coefficient estimates presented in Tables 3 and 4 is highly unlikely.

The second concern with regard to the estimated treatment effects is the possible trade-off between schooling and extracurricular investments addressed above. Due to the methodological reasons already mentioned, we have estimated separate models with available leisure as a dependent variable and the four specifications employed for the personality models. We hereby implicitly assume independence of the error terms in both equations. The leisure variable is constructed by using information on the weekly mandatory curriculum and statements from the questionnaire regarding additional elective courses and hours spent on several extracurricular tasks (homework, learning, chore, taking care of siblings etc.). The respective results are presented in Table 7. Neither for males nor for females we find a significant and conclusive effect of the dummy on disposable leisure in hours per week. We therefore conclude that there is no relevant trade-off between extracurricular and schooling investments that may veil the impact of the increased learning intensity. Moreover, given the unambiguous result, we do not need to relax the independence assumption.

Table 7: Regression of leisure (hours per week) on specifications 1 to 4

\begin{tabular}{lrr}
\hline \hline & (male) & (female) \\
\hline Specification 1 & 2.482 & -0.053 \\
& $(1.764)$ & $(1.336)$ \\
\hline Specification 2 & 2.014 & 0.075 \\
& $(1.732)$ & $(1.356)$ \\
\hline Specification 3 & 2.341 & 0.177 \\
& $(1.835)$ & $(1.329)$ \\
\hline Specification 4 & 1.922 & 0.263 \\
& $(1.798)$ & $(1.349)$ \\
\hline \hline
\end{tabular}

${ }^{*} p<0.1,{ }^{* *} p<0.05,{ }^{* * *} p<0.01$ (Standard errors in parentheses)

See section 4.2 for details on the specifications.

\section{Conclusion}

Little is known about the impact of schooling characteristics on the expression of noncognitive skills in late adolescence. This paper has analyzed the effect of an approximate 20 percent increase in learning intensity on nine measures of personality, comprising the Big Five, Locus of Control, Self-Control, and Positive and Negative Reciprocity. The empirical analysis explored a natural experiment induced by an educational policy reform in the German federal state of Saxony-Anhalt, were the last year of higher secondary schooling was abolished for students in ninth grade in 2003, leaving students in the tenth grade at that time unaffected. Based on data of the double cohort of graduates in 2007, 
differences in various outcomes between both groups can be addressed to be causally a result of the reform. The empirical results suggest, that there is no significant effect of the reform on any of the personality scores we considered. Moreover, we showed that no simultaneous age effect of the older cohort confounds the estimated treatment effects, nor that there is a trade-off between schooling and extracurricular investments.

Referring to the skill formation literature, the most salient explanation for our findings is that personality is fairly well set at the age of higher secondary schooling and (scholastic) environmental changes do not have the same impacts as those established in earlier periods in life. Moreover, the change in schooling intensity in late adolescence seems to be only a minor input variation compared to the more crucial role that preschool, primary school and early adolescence investments play. The analysis of the background characteristics revealed that both cohorts were on average equally endowed with these inputs before the reform was implemented. Therefore, the consensus view that higher academic requirements at school come at the expense of the free personality development of the individual cannot be supported. This result is also promoted by the fact that we did neither find a systematic age effect nor indications of a trade-off between curricular and extracurricular investments. A further argument against a trade-off between curricular and extracurricular activities is that the picture for the nine personality dimensions would have been less unequivocal, since different periods of schooling do not foster all personality dimensions in the same manner.

With respect to the external validity of the results, some points remain to be discussed. The effect of intensification on students' personality may vary with previous levels of learning intensity. Since the intensity in the university preparatory track prior to the reform was already very high, a remission in other personality shaping activities outside the school is unlikely. For lower educational tracks, however, it may be more reasonable to assume such a trade-off. On the other hand, the role noncognitive skills play regarding track choices may have produced a selected sample in terms of noncognitive skill endowments prior to the reform. In this case the effects for lower secondary schooling tracks may be supposably lower. Moreover, the increase in learning intensity implemented due to the reform only affected the end of schooling time. Given the nature of skill formation, an implementation at the middle of the schooling stretch may induce different effects.

Generally, natural experiments induced by policy changes entail the risk of an initial adjustment reaction of the participants that may bias the actual effect. If the affected students and their parents try to adjust changes at school, this is not just an occurrence of the first graduation year we observe. Since graduation is unique, for most of them a change in behavior of the ensuing years is not expected. For teachers, such an adjustment reaction may play a more important role. Initially, they may have put in some extra effort in order to help the students to cope with the increased intensity and may have decreased this effort for subsequent classes. However, in this case the above-mentioned argument that the picture would be less unequivocal for the various personality dimensions remains. As different personality dimensions are varyingly susceptible to increased teacher effort we probably would have observed different effects across them. 
In order to check the assumption of a natural experiment and to raise the precision of the estimates, we tested four model specifications for each personality trait. This provides some nice insights into the relevance of various background characteristics. Summarizing the results along all dimensions, there are certain parental characteristics (like employment status, working position, religion) exerting major influences on the development of the descendant's personality. Likewise, there are specific home resources seemingly discriminating parents in terms of parental skills, like the 'artifacts at home' item. These items, therefore, seem to be indicators for other, unobservable driving forces.

This paper sheds light on the plasticity of personality traits in terms of schooling investments at the end of adolescence. This period is yet not captured by other data sets used in the empirical skill formation literature. For our sample, which considers a wide socioeconomic family background, the substantial change in schooling intensity has no lasting impact on students' personality at this age. Our results are therefore in line with previous findings in the economic and psychological field. They indicate that instead of very general skills as those captured by personality tests, later secondary schooling rather promotes the acquisition of more specific competencies.

\section{References}

Akaike, H. (1973): "Information Theory and an Extension of the Maximum Likelihood Principle," in Second International Symposium on Information Theory, ed. by B. Petrov, and F. Csake. Akademiai Kiado.

Blonigen, D. M., M. D. Carlson, B. M. Hicks, R. F. Krueger, and W. G. Iacono (2008): "Stability and Change in Personality Traits From Late Adolescence to Early Adulthood: A Longitudinal Twin Study," Journal of Personality, 76(2), 229-266.

Borghans, L., A. L. Duckworth, J. Heckman, and B. ter Weel (2008a): "The Economics and Psychology of Personality Traits," Journal of Human Resources, 43(4), 972-1059.

Borghans, L., H. MeiJers, and B. ter Weel (2008b): "The Role of Noncognitive Skills in Explaining Cognitive Test Scores," Economic Inquiry, 46(1), 2-12.

Bowles, S., H. Gintis, And M. Osborne (2001): "The Determinants of Earnings: A Behavioral Approach," Journal of Economic Literature, 38(4), 1137-1176.

Braakmann, N. (2009): "The Role of Psychological Traits for the Gender Gap in Full-Time Employment and Wages: Evidence from Germany," DIW Discussion Papers 162, German Institute for Economic Research (DIW), Berlin.

Büttner, B., And S. L. Thomsen (2010): "Are We Spending too Many Years in School? Causal Evidence of the Impact of Shortening Secondary School Duration," ZEW Discussion Paper 10-011, Centre of European Economic Research (ZEW), Mannheim. 
Cronbach, L. J. (1951): "Coefficient Alpha and the Internal Structure of Tests," Psychometrika, $16(3), 297-334$.

Cunha, F., and J. Heckman (2006): "Investing in our Young People," unpublished, available at http://www-news.uchicago.edu/releases/06/061115.education.pdf.

(2007): "The Technology of Skill Formation," American Economic Review, 97(2), 31-47.

(2008): "Formulating, Identifying and Estimating the Technology of Cognitive and Noncognitive Skill Formation," Journal of Human Resources, 43(4), 738-782.

(2009): "The Economics and Psychology of Inequality and Human Development," Journal of the European Economic Association, 7(2/3), 320-364.

Cunha, F., J. Heckman, and S. Schennach (2010): "Estimating the Technology of Cognitive and Noncognitive Skill Formation," Econometrica, 78(3), 883-991.

DAHL, R. E. (2004): "Adolescent Brain Development: A Period of Vulnerabilities and Opportunities," in Annals of the New York Academy of Sciences 1021, pp. 1-22. New York Academy of Sciences.

Dehne, M., And J. Schupp (2007): "Persönlichkeitsmerkmale im Sozio-ökonomischen Panel (SOEP) - Konzept, Umsetzung und empirische Eigenschaften," Research Note 26, German Institute for Economic Research (DIW), Berlin.

Destatis (2009): Allgemeine Schulen-Schuljahr 2008/09, Fachserie 11 Reihe 1-2008/09. Statistisches Bundesamt Deutschland, Wiesbaden.

Dohmen, T., A. Falk, D. Huffman, and U. Sunde (2009): "Homo Reciprocans: Survey Evidence on Behavioral Outcomes," Economic Journal, 119, 592-612.

Duckworth, A. L., And M. Seligman (2005): "Self-Discipline Outdoes IQ in Predicting Academic Performance of Adoloscents," American Psychological Society, 16(12), 939-944.

Fehr, E., And S. Gächter (2000): "Fairness and Retaliation: The Economics of Reciprocity," Journal of Economic Perspectives, 14(3), 159-181.

GoldberG, L. (1971): "A Historical Survey of Personality Scales and Inventories," in Advances in Psychological Assessment, ed. by P. McReynolds, pp. 293-336. Science and Behavior Books, Palo Alto, California.

Gupta, N. D., And M. Simonsen (2010): "Non-Cognitive Child Outcomes and Universal High Quality Child Care," Journal of Public Economics, 94(1), 30-43.

Heckman, J. (2007): "The Economics, Technology and Neuroscience of Human Capability Formation," Proceedings of the National Academy of Sciences of the United States of America, 104(33), 13250-13255. 
Heckman, J., S. H. Moon, R. Pinto, P. A. Savelyev, and A. Yavitz (2010): "The Rate of Return to the High Scope Perry Program," Journal of Public Economics, 94(1/2), 114-128.

Heckman, J., J. Stixrud, and S. Urzua (2006): "The Effects of Cognitive and Noncognitive Abilities on Labor Market Outcomes and Social Behavior," Journal of Labor Economics, 24(3), $411-482$.

Heineck, G., And S. Anger (2010): "The Returns to Cognitive Abilities and Personality Traits in Germany," Labour Economics, 17(3), 535-546.

Hogan, R., And J. Hogan (2007): Hogan Personality Inventory Manual, Third Edition. Hogan Assessment Systems, Tulsa, OK.

Mueller, G., and E. Plug (2006): "Estimating the Effect of Personality on Male and Female Earnings," Industrial and Labor Relations Review, 60(1), 3-22.

Nandi, A., And C. Nicoletti (2009): "Explaining Personality Pay Gaps in the UK," ISER Working Paper Series 2009-22, Institute for Social and Economic Research, University of Essex.

O'Connor, M. C., and S. V. Paunonen (2007): "Big Five Personality Predictors of Post-Secondary Academic Performance," Personality and Individual Differences, 43, 971-990.

OECD (2005): Education at a Glance. OECD, Paris.

Poropat, A. E. (2009): "A Meta-Analysis of the Five-Factor Model of Personality and Academic Performance," Psychological Bulletin, 135(2), 322-338.

Roberts, B. W., W. Viechtbauer, and K. E. Walton (2006): "Patterns of Mean-Level Change in Personality Traits Across the Life Course: A Meta-Analysis of Longitudial Studies," Psychological Bulletin, 132(1), 1-25.

Rotter, J. (1966): Generalized Expectancies for Internal versus External Control of Reinforcement. American Psychological Association, Washington, DC.

Silverman, B. W. (1986): Density Estimation for Statistics and Data Analysis. Chapman and Hall, London.

Tangney, J., R. Baumeister, and M. Boone (2004): "High Self-Control Predicts Good Adjustment, Less Pathology, Better Grades, and Interpersonal Success," Journal of Personality, 72(2), $271-322$.

Thiel, H., and S. Thomsen (2009): "Noncognitive Skills in Economics: Models, Measurement, and Empirical Evidence," ZEW Discussion Paper 09-076, Centre for European Economic Research (ZEW), Mannheim.

Todd, P., And K. Wolpin (2007): "The Production of Cognitive Achievement in Children: Home, School and Racial Test Score Gaps," Journal of Human Capital, 1(1), 91-136. 
Viinikainen, J., K. Kokko, L. Pulkkinen, and J. Pehkonen (2010): "Personality Traits and Labour Market Income: Evidence from Longitudinal Data," LABOUR: Review of Labour Economics and Industrial Relations, 24(2), 201-220.

Weiss, C. (2010): "The Effects of Cognitive and Noncognitive Abilities on Earnings: Different School Systems," unpublished.

White, H. (1980): "A Heteroskedasticity-Consistent Covariance Matrix Estimator and a Direct Test of Heteroskedasticity," Econometrica, 48, 817-838.

Wichert, L., And W. Pohlmeier (2010): "Female Labor Force Participation and the Big Five," ZEW Discussion Paper 10-003, Centre of European Economic Research (ZEW), Mannheim. 


\section{A Appendix: Personality Tests included in the Questionnaire}

\section{Big Five}

I see myself as someone who...

1. is original, comes up with new ideas (Openness to Experience).

2. values artistic experiences (Openness to Experience).

3. has an active imagination (Openness to Experience).

4. does a thorough job (Conscientiousness).

5. does things effectively and efficiently (Conscientiousness).

6. tends to be lazy (Conscientiousness, reversed).

7. is communicative, talkative (Extraversion).

8. is outgoing, sociable (Extraversion).

9. is reserved (Extraversion, reversed).

10. is sometimes somewhat rude to others (Agreeableness, reversed).

11. has a forgiving nature (Agreeableness).

12. is considerate and kind to others (Agreeableness).

13. worries a lot (Neuroticism).

14. gets nervous easily (Neuroticism).

15. is relaxed, handles stress well (Neuroticism, reversed).

\section{Locus of Control (LOC)}

Using the scale provided, indicate what your attitudes towards life and towards your own future are.

1. How my life goes depends on me (Internal LOC).

2. If a person is socially or politically active, he/she can have an effect on social conditions (Internal LOC).

3. One has to work hard in order to succeed (Internal LOC).

4. If I run up against difficulties in life, I often doubt my own abilities (reversed, Internal LOC).

5. Compared to other people, I have not achieved what I deserve (External LOC).

6. What a person achieves in life is above all a question of fate or luck (External LOC).

7. I frequently have the experience that other people have a controlling influence over my life (External LOC).

8. The opportunities that I have in life are determined by the social conditions (External LOC).

9. Inborn abilities are more important than any efforts one can make (External LOC).

10. I have little control over the things that happen in my life (External LOC). 


\section{Brief Self-Control Scale}

Using the scale provided, please indicate how much each of the following statements reflects how you typically are.

1. I am good at resisting temptation.

2. I have a hard time breaking bad habits (reversed).

3. I say inappropriate things (reversed).

4. I do certain things that are bad for me, if they are fun (reversed).

5. I refuse things that are bad for me.

6. I wish I had more self-discipline (reversed).

7. People would say that I have iron self-discipline.

8. Pleasure and fun sometimes keep me from getting work done (reversed).

9. I have trouble concentrating (reversed).

10. I am able to work effectively toward long-term goals.

11. Sometimes I can't stop myself from doing something, even if I know it is wrong (reversed).

\section{Reciprocity}

Using the scale provided, please indicate how much each of the following statements reflects how you typically are.

1. If someone does me a favor, I am prepared to return it (Positive Reciprocity).

2. I go out of my way to help somebody who has been kind to me before (Positive Reciprocity).

3. I am ready to undergo personal costs to help somebody who helped me before (Positive Reciprocity).

4. If I suffer a serious wrong, I will take revenge as soon as possible, no matter what the cost (Negative Reciprocity).

5. If somebody puts me in a difficult position, I will do the same to him/her (Negative Reciprocity).

6. If somebody offends me, I will offend him/her back (Negative Reciprocity). 


\section{B Appendix B: Kernel Densities}
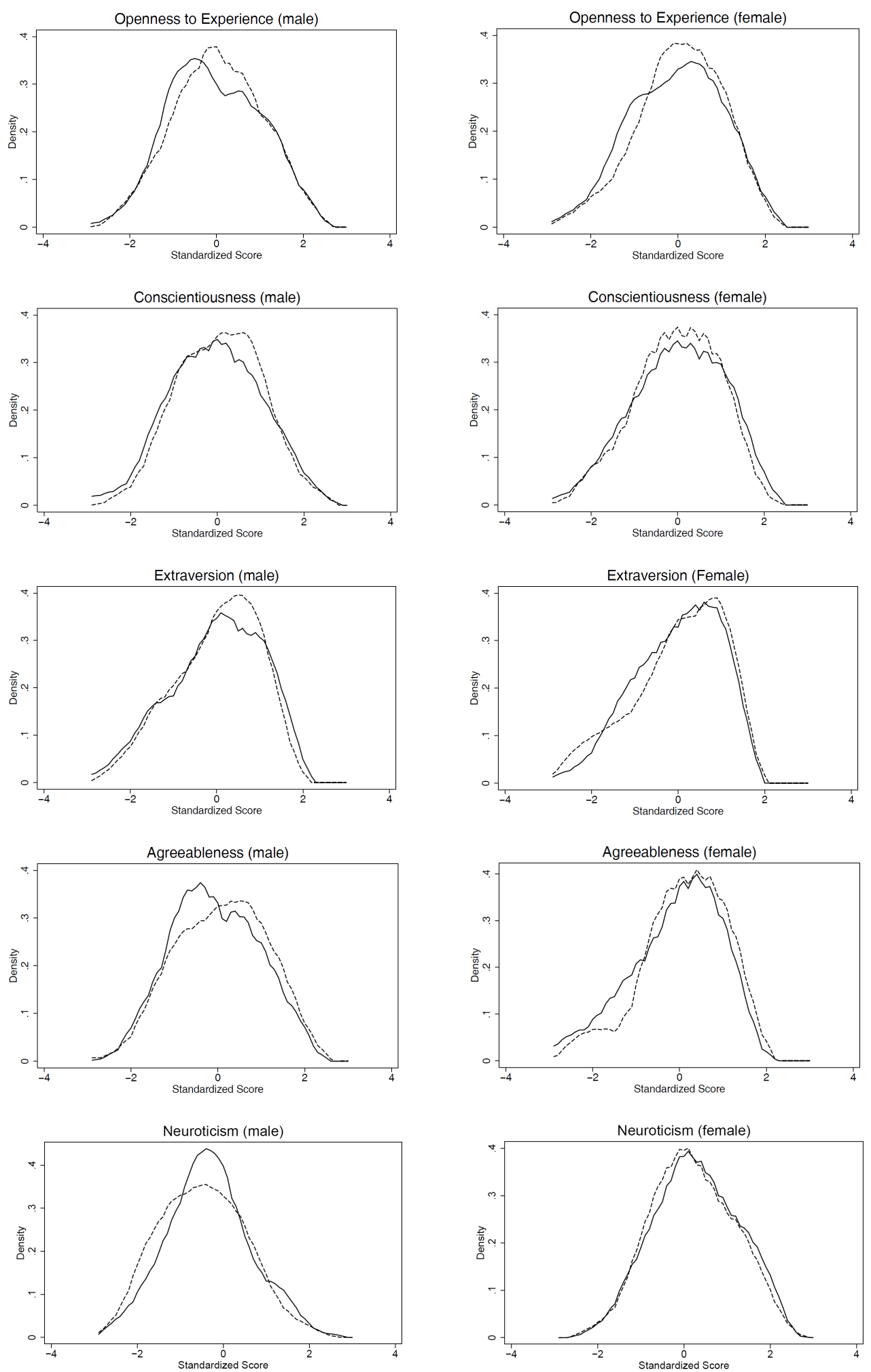

Figure 1: Kernel densities of the Big Five dimensions for treatment and control group (G12 dashed, G13 solid) by gender. Kernel: Epanechnikov with Silverman bandwidth estimate (see Silverman, 1986) 

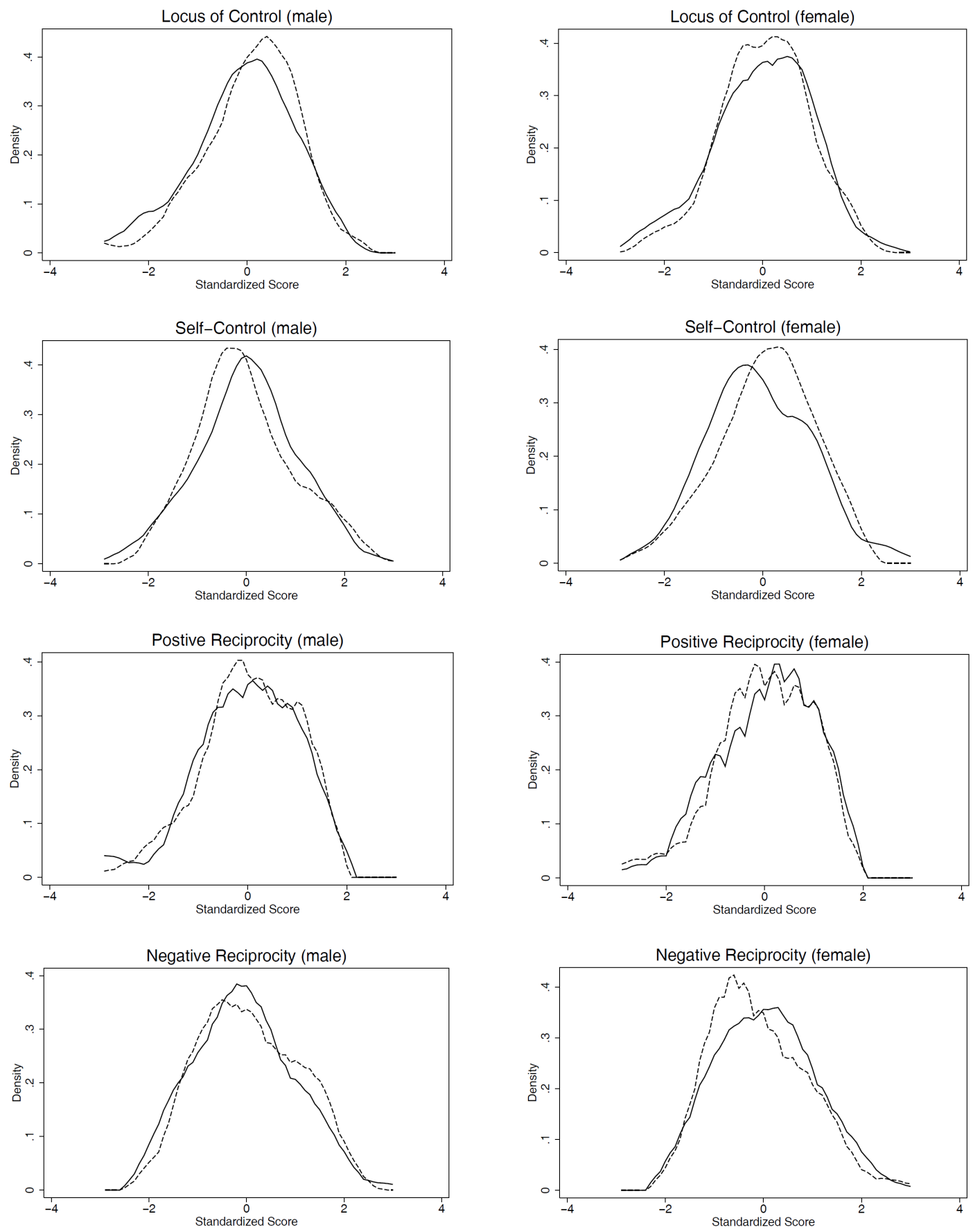

Figure 2: Kernel densities of the remaining personality scales for treatment and control group (G12 dashed, G13 solid) by gender. Kernel: Epanechnikov with Silverman bandwidth estimate (see Silverman, 1986) 